\title{
Content of Heavy Metals and Their Fractions in Organic Soils of Podlasie
}

\author{
Józefa Wiater ${ }^{1}$ \\ 1 Department of Environmental Engineering Technology and Systems, Bialystok University of Technology, \\ Wiejska 45A, 15-351 Białystok, Poland, e-mail: j.wiater@pb.edu.pl
}

\begin{abstract}
The purpose of this study was to determine the total content of cadmium, lead, nickel, copper, zinc and their fractions in organic soils of Podlasie used as permanent grassland. The research material were samples taken from 30 soils of the Podlasie province in 2011-2013. The samples were taken from the determined layer to depth of 0-30 cm. Basic physicochemical properties were determined in the taken soil samples: organic carbon content, $\mathrm{pH}$ in $1 \mathrm{M} \mathrm{KCl}$ potentiometrically. The total content of metals after mineralization in aqua regia was determined, and cadmium fractions were determined with a modified BCR method. The measurements were conducted by means of atomic absorption spectroscopy with electrothermal atomization using Varian AA-100 spectrometer. It was found that only 2 soils can be included in the soils with first pollution degree due to the cadmium content. The content of other metals was at geochemical background level. The distribution of investigated metals in the fractions in studied organic soils was different comparing to mineral soils. Most of the analyzed elements were present in the fraction associated with organic substance, which limited their mobility, as evidenced by their low share in the available and potentially available fraction. The proportion of metals in the residual fraction was low, which is typical for organic soils. The share of studied metals in particular fractions varied depending on the sampling date, which may be related to the climatic conditions course in the study period and the treatments performed on these soils.
\end{abstract}

Keywords: heavy metal, organic soils, speciation of heavy metals

\section{INTRODUCTIONS}

The main source of heavy metals in organic soils is the soil itself, because it is being formed due to organic matter accumulation. Peat, as reported by Hornburg and Brummer [1993] and Kabata-Pendias, Pendias [1999], has the ability to sorb and bind metals, accumulating them not only from dying biomass, but also from atmospheric depositions. Only some metals are washed out in small amounts to deeper layers, so their accumulation occurs mainly in the top layer. The content of metals in these soils is an environment quality indicator over many years [Kabała et al. 1998]. In organic soils, metals are strongly sorbed by organic matter, which may limit their mobility.

However, this condition may change under the influence of human activity, when these soils are used for agricultural purposes in the form of grasslands and are subject to agrotechnical measures that change their properties. This, in turn, affects the availability and solubility of these metals in the soil. The metals found in the most mobile fractions (acid-soluble and exchangeable), as well as elements that are released under influence of changing environmental conditions, i.e. potentially mobile fractions (reductive and oxidation) are directly available for plants. This form of occurrence of the element in the soil, and not its total content in soil, plays a significant role in its movement along the water-soil-plant-animal-human chain.

The bioavailability for plants of elements contained in soil depends on its $\mathrm{pH}$, oxidation reduction conditions, granulometric composition, organic matter content, $\mathrm{Fe}, \mathrm{Mn}, \mathrm{Al}$ and microorganisms, interactions between elements, as well as the element form and its susceptibility to transition from solid to liquid soil phase [Moćko and Wacławek 2004, Finžgar et al. 2007] 
The purpose of this work was to determine the total content of cadmium, lead, nickel, copper and zinc and their fractions share in Podlasie organic soils used as permanent grassland.

\section{METERIALS AND METHODS}

In 2013 and 2014, the organic soils samples were collected at fifteen points in the Podlasie voivodship. These were peat soils and were used as permanent grassland. Basic physicochemical properties were determined in the soil samples: organic carbon content in accordance to Tiurin method, $\mathrm{pH}$ in $1 \mathrm{M} \mathrm{KCl}$ potentiometric. Soils were also determined in the form of available phosphorus, potassium in accordance to Egner-Riehm and magnesium with Schashtschabel method.

Thereafter, the total content of metals after mineralization in aqua regia was determined by means of atomic spectrometry with flame atomization. These determinations were carried out once in 2014. Before the determination of metal fractions, sequential extraction procedure of heavy metals $(\mathrm{Ni}, \mathrm{Pb}, \mathrm{Cd}, \mathrm{Cu}, \mathrm{Zn})$ from soils was developed. Ultrasound was used as acceleration of classic extraction process, which allowed to shorten the analytical procedure from about 50 hours to several minutes. In the samples taken in the next two years, the determination of metal fractions was carried out with modified BCR method [Rauret et al. 1999]. This method includes the extraction of exchangeable metals and water-soluble and weak acids (fraction 1), using acetic acid $\left(0.11 \mathrm{~mol} \cdot \mathrm{m}^{-3}\right)$. The metals associated with iron and manganese hydroxides (fraction 2) are extracted with hydroxylamine hydrochloride $\left(0.5 \mathrm{~mol} \cdot \mathrm{dm}^{-3}\right)$. The next fraction of metals is bound to organic matter (fraction 3), which is released by hydrogen peroxide and ammonium acetate $\left(0.5 \mathrm{~mol} \cdot \mathrm{dm}^{-3}, \mathrm{pH}=2\right)$. Residues (residual fraction) were determined after extraction in aqua regia, in order to control the internal method. Determinations of metals and their fractions were made by means of atomic absorption spectroscopy with electrothermal atomization using Varian AA-100 spectrometer.

\section{RESULTS}

The studied soils were in the range from acidic to neutral, depending on their $\mathrm{pH}$. Organic carbon was on average over $27 \%$, the median value indicates that the carbon content in most soils oscillated around $27 \%$. The phosphorus content was mostly low, potassium very low, and the magnesium average by fertile classes for these compounds.

The $\mathrm{Cu}$ content in Podlasie organic soils (Fig. 1) ranged from 1.3 to $48.2 \mathrm{mg} \cdot \mathrm{kg}^{-1}$ in accordance to Mock [2002]. Only a small part of this element is stored in soil in a easily soluble and exchangeable form and constitutes on average $10-17 \%$ of total $\mathrm{Cu}$. In the studied soils, $\mathrm{Cu}$ is strongly bound by organic matter and its share in the third fraction is $33-52 \%$; a small amount of this metal in fraction four indicates low availability in studied soils, which is consistent with the research of other researchers [Kabata-Pendias and Pendias 1999, Moćko and Wacławek 2004, Mendoza et al. 2006]. A certain pool of $\mathrm{Cu}$ available for plants may be its share in the second potentially available fraction, which varies within quite wide range from 10-30\% (Fig.2)

Among the investigated soils, due to the total $\mathrm{Cd}$ content, only 2 can be included in the soils with the first pollution degree and the remaining ones are in the geochemical background (Fig. 1). The Cd content in the analyzed soils was similar to the range for Polish soils from 0.03 to $1.35 \mathrm{mg} \cdot \mathrm{kg}^{-1}$ given by Mock [2002]. The distribution of $\mathrm{Cd}$ in the analyzed fractions was slightly different than in mineral soils (Fig. 3). Cadmium in unpolluted mineral soils is mainly bound by the residual fraction [DąbkowskaNaskręt 1997, Kabata-Pendias and Pendias 1999, Morera et al. 2001]. The high mobility

Table 1. Selected soil properties

\begin{tabular}{|l|c|c|c|c|c|}
\hline \multicolumn{1}{|c|}{ Basic statistics } & $\mathrm{pH}$ & Organic C [\%] & $\begin{array}{c}\text { Assomilable P } \\
{\left[\mathrm{mg}^{\left.-100 \mathrm{~g}^{-1}\right]}\right.}\end{array}$ & $\begin{array}{c}\text { Assomilable K } \\
{\left[\mathrm{mg} \cdot 100 \mathrm{~g}^{-1}\right]}\end{array}$ & $\begin{array}{c}\text { Assomilable Mg } \\
{\left[\mathrm{mg}^{\left.-100 \mathrm{~g}^{-1}\right]}\right.}\end{array}$ \\
\hline Arithmetic mean & - & 27.6 & 102.5 & 18.9 & 72.9 \\
\hline Median & - & 26.7 & 61.6 & 13.6 & 77.6 \\
\hline Standard deviation & - & 10.7 & 97.9 & 15.1 & 32.1 \\
\hline Minimum & 5.2 & 11.8 & 33.3 & 8.0 & 13.2 \\
\hline Maximum & 7.0 & 42.5 & 379.9 & 61.0 & 131.2 \\
\hline
\end{tabular}




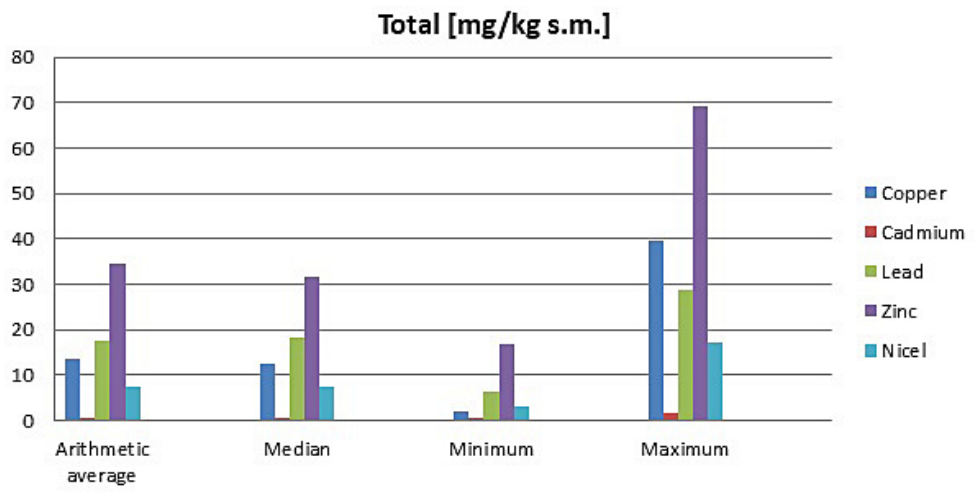

Fig. 1. Total content of studied heavy metals in organic soils

of cadmium in soils is confirmed by the total content of this element in other fractions extracted from studied soil, which are, to varying degrees, phytopassacious [Gray, in 2000, Pueyo et al. 2003, Moćko and Wacławek 2004]. Biernacka and Małuszyński [2007] stated, examining the soil from the area considered unpolluted within six years, that $61.6 \% \mathrm{Cd}$, in accordance to total content, was associated in the fractions available and potentially available to plants (exchangeable fraction, soluble in acids, reducible and oxidizable). In the studied organic soils, the $\mathrm{Cd}$ share in residual fraction during three study years did not exceed $30 \%$. Most cadmium was concentrated in the third fraction associated with organic substance and in the first year it was almost $40 \%$, and in second and third $-50 \%$. The most available fraction was over $10 \%$, and potentially available over $20 \%$. The differences in the share of individual fractions in total $\mathrm{Cd}$ of studied soils during the research period result from variable environmental conditions as indicated by Broos et al. [2001].
There was more total $\mathrm{Pb}$ in organic soils than in mineral soils, which amounts to $13.5 \mathrm{mg} \cdot \mathrm{kg}^{-1}$ in accordance to Mocek [2001]. In the studied organic soils, the $\mathrm{Pb}$ content was on average $18 \mathrm{mg} \cdot \mathrm{kg}^{-1}$, and maximum value was nearly $30 \mathrm{mg} \cdot \mathrm{kg}^{-1}$, but all the examined soils were uncontaminated (Fig. 1). Unlike in mineral soils, the fraction of this metal decomposed (Fig. 4). The share in the residual fraction did not exceed $20 \%$, and for mineral soils, as many authors state [Jackowska and Bojanowska 2000, Niesiobędzka 2001, Biernacka and Małuszyński 2007], the share of lead is the greatest. It also shows a clear tendency to combine with organic matter [Dąbkowska-Naskręt 1997, Kabata-Pendias and Pendias 1999, Moćko and Wacławek 2004, Finžgar et al. 2007] as indicated by the $\mathrm{Pb}$ share in third fraction in analyzed soils. The least $\mathrm{Pb}$ was present in the exchangeable fraction [Sabienë et al. 2004, Ramos et al. 1994, Finžgar et al. 2007]. In the studied soils, the most lead was in the second reducible fraction, which is not typical for organic soils. The larger $\mathrm{Pb}$ amount in this

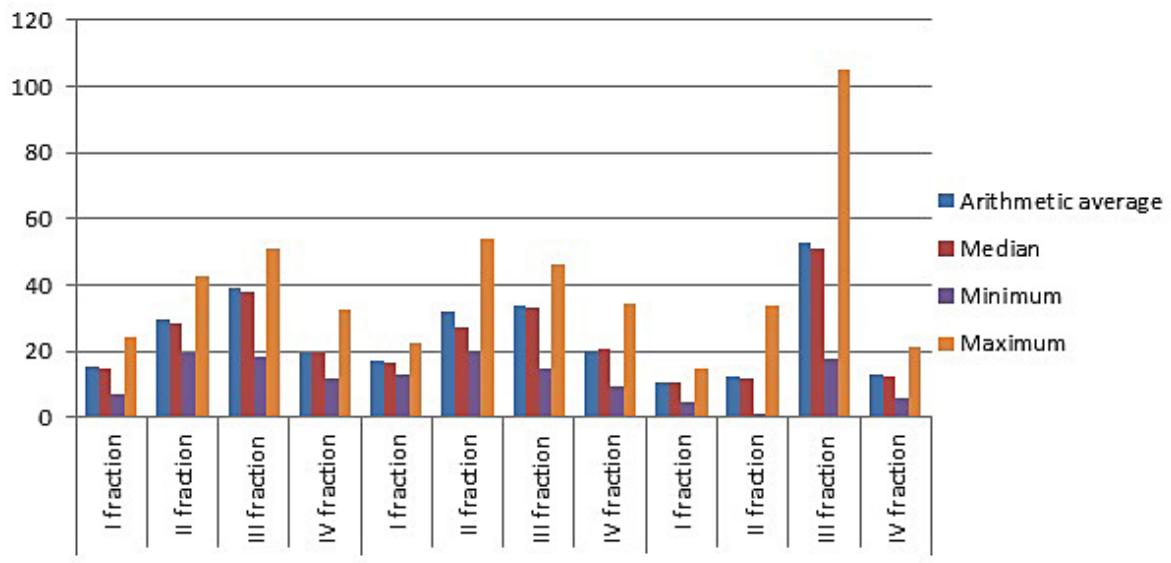

Fig. 2. $\mathrm{Cu}$ share in studied fractions in comparison to its total concentration 


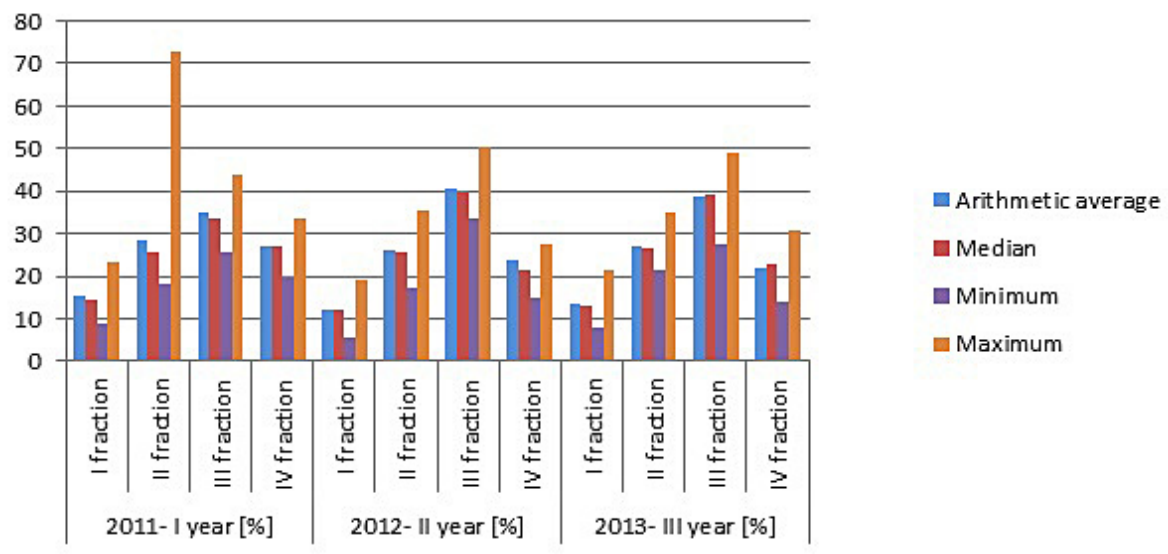

Fig. 3. Cd share in the studied fractions in comparison to its total concentration

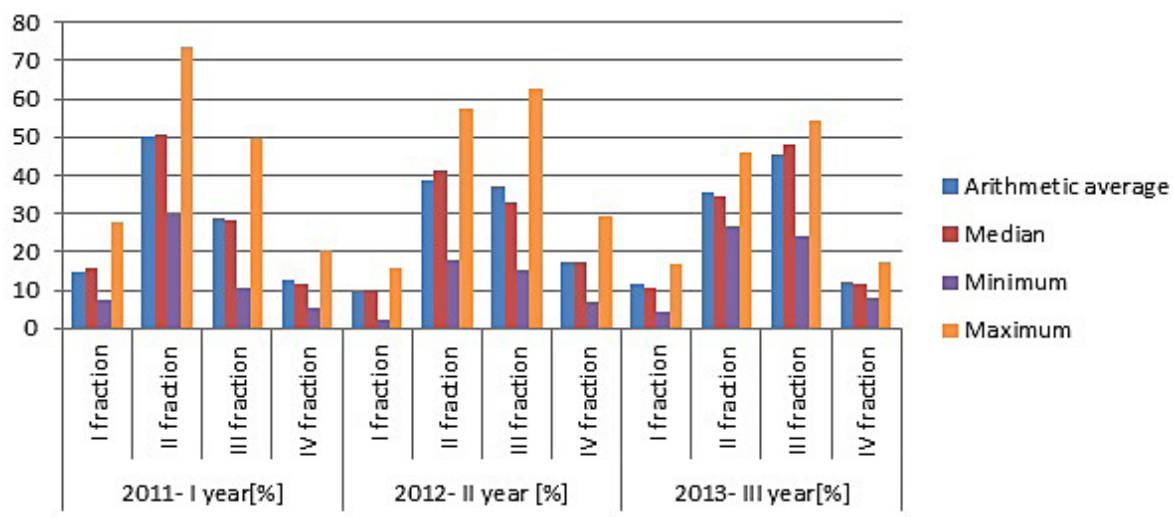

Fig. 4. $\mathrm{Pb}$ share in the studied fractions in comparison to its total concentration

fraction may be influenced not only by the agricultural use of these soils but also by the anthropogenic deposition in the form of dust.

The average $\mathrm{Zn}$ content in uncontaminated Polish arable soils is $32.4 \mathrm{mg} \cdot \mathrm{kg}^{-1}$, in the range from 10.9 to $142.8 \mathrm{mg} \cdot \mathrm{kg}^{-1}$ [Mocek 2002], in the studied soils $\mathrm{Zn}$ was ranging from 18 to $70 \mathrm{mg} \cdot \mathrm{kg}^{-1}$ (Fig. 1). The Zn share in the studied fractions varied depending on the research year (Fig. 5). The lowest $\mathrm{Zn}$ content was in the available and residual fractions. The availability of zinc contained in soil depends on: $\mathrm{pH}$, total $\mathrm{Zn}$ content, organic matter and calcium carbonate content, redox conditions, microbial activity in the rhizosphere, soil moisture, content of other trace metals and macronutrients (especially phosphorus) in soil, as well as climatic conditions [Alloway 2004]. The organic matter content in the studied soils reduced this metal mobility, because the share in the third fraction was the highest and ranged from nearly 40 to $50 \%$. The lowest $\mathrm{Zn}$ content was in residual fraction, which indicates the organic soils specificity, because in mineral soils the share in this fraction may be in the range $69 \div 83 \%$, according to Mendoza et al. [2006].

The nickel content in Polish soils, as reported in [Report 2000], is very wide and ranges from 0.4 to $46.5 \mathrm{mg} \cdot \mathrm{kg}^{-1}$. In the studied organic soils, a similar range of total nickel contents was noted (Fig. 1). The distribution of nickel in particular fractions was similar and little differentiated in study period (Fig. 6). The first fraction share in the total Ni content was about $20 \%$, in the second $25 \%$, in third about $30 \%$ and in fourth about 25\%. Sergin and Kozhevnikova [2006] report that the Ni mobility depends on soil moisture content, organic matter content and increases under low $\mathrm{pH}$ conditions. Most of the studied soils were characterized by high $\mathrm{pH}$ and high content of organic matter which limited nickel mobility. In the most mobile fractions (soluble in water and exchangeable) in unpolluted soils, the nickel content is generally the smallest [Barona and Romero 1997, Kabata-Pendias and Pendias 1999, Hall and Pelchat 1999], which is 


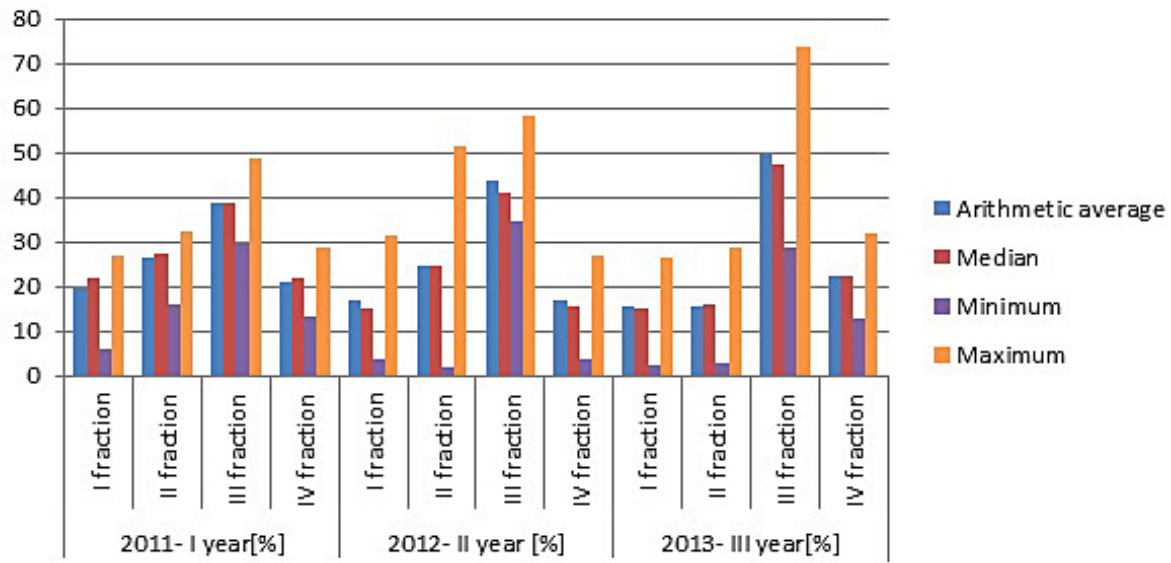

Fig. 5. $\mathrm{Zn}$ share in studied fractions in comparison to its total concentration

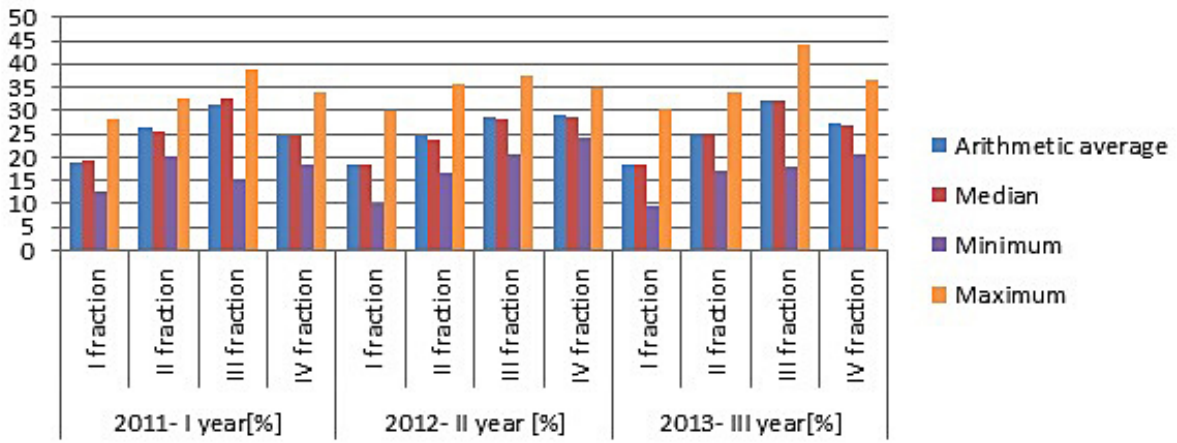

Fig. 6. Ni share in studied fractions in comparison to its total concentration

consistent with the obtained results. Moćko and Wacławek [2004] argue that the largest amounts of nickel are bound in the soil by the residual fraction, but their research concerns mineral soils and this cannot be referred to studied organic soils.

\section{CONCLUSSIONS}

1. The examined organic soils were uncontaminated due to total heavy metals content, with the exception of two soils with an increased content of cadmium.

2. Metals distribution in individual fractions resulted from the specificity of organic soils.

a) Most metals occurred in the third fraction related to organic matter and their share was over $50 \%$, with the exception of nickel, the share of which in this fraction was about $30 \%$.

b) The heavy metals content in the residual fraction was at the level of 20 to $25 \%$.

c) The share of metals in the mobile fraction did not exceed $20 \%$, and the potentially mobile one was higher and exceeded $20 \%$.

\section{REFERENCES}

1. Alloway B.J. 2004. Zinc in Soils and Crop Nutrition, International Zinc Association, Brussels, Belgium.

2. Barona A., Romero F. 1997. Relationships among metals in the solid phase of soils and in wild plants. Water Air Soil Pollution, 95, 59-74.

3. Biernacka E., Małuszyński M.J. 2007. Forms of lead and cadmium in the top layers of soils of two selected areas with varying degrees of environmental pollution. Environmental Protection and Natural Resources, 31, 101-105. (in Polish)

4. Broos K., DeGryse F., Smolders E. 2001. Cadmium and zinc availability and toxicity to symbiotic nitrogen fixation in soils contaminated by various sources. Proceedings of the 6th International Conference on the Biogeochemistry of Trace Elements, Guelph, Ontario, Canada.

5. Dąbkowska-Naskręt H. 1997. The application of $\mathrm{BCR}$ extraction procedure for $\mathrm{Cd}$ and $\mathrm{Pb}$ mobility determination in arable soils. Polish Journal of Soil Science, 30, 29-33.

6. Finžgar N., Tlustoš P., Leštan D. 2007. Relationship of soil properties to fractionation, bioavailability and mobility of lead and zinc in soil. Plant 
Soil Environment, 53, 225-238.

7. Gray C.W., McLaren R.G., Roberts H.C., Condron L.M. 2000. Fractionation of soil cadmium from some New Zealand soils. Communications in Soil Science and Plant Analysis, 31, 1261-1273.

8. Hall G. E. M., Pelchat P. 1999. Comparibility of results obtained by the use of different selective extraction schemes for the determination of element forms in soils. Water Air Soil Pollution, 112, 41-53.

9. Hornburg V.,Brummer G.W.1993.Verhaltenvon Schwermetallen in Boden. 1 Untersuchungen zur Schwermetallmobilitat. Z Pflanzenernahr Bodenk $156,467-477$

10. Jackowska I., Bojanowska M. 2000. Research on the forms and solubilities of heavy metals in loess soil. Soil Science Annual, 51, 65-72. (in Polish)

11. Kabała C., Walkiewicz A., Karczewska A. 1998. Trace elements in peat profiles from the Great Peatbog Batorowski in Góry Stołowe. Szczeliniec 2, 15-21. (in Polish)

12. Kabata-Pendias A., Pendias H.1999. Biogeochemistry of trace elements. PWN, Warsaw. (in Polish)

13. Mendoza J., Garrido T., Castillo G., Nilsa S.M. 2006. Metal availability and uptake by sorghum plants grown in soils amended with sludge from different treatments. Chemosphere 65, 2304-2312.

14. Mocek A. 2002. Degrees of contamination of Polish soil with heavy metals. Journal of Research and Applications in Agricultural Engineering,
47, 29-34. (in Polish)

15. Moćko A., Wacławek W. 2004. Three-step extraction procedure for determination of heavy metals availability to vegetables. Analytical and Bioanalytical Chemistry, 380, 813-817.

16. Niesiobędzka K. 2001. Specjacja metali ciężkich w aspekcie właściwości gleb. Gworek B., Mocek A. (red.), Obieg pierwiastków w przyrodzie. Monografia t.I IOŚ, Warszawa, 55-61.

17. Pueyo M., Sastre J., Hernandez E., Vidal M., Lopez-sanchez J. F., Rauret G. 2003. Prediction of trace element mobility in contaminated soils by sequential extraction. Journal of Environmental Quality, 32, 2054-2066.

18. Michna W. 1999. Report on monitoring the quality of soils, plants, agricultural and food products. Warszaw. (in Polish)

19. Rauret G., López-Sánchez J. F., Sahuquillo A., Rubio R., Davidson C., Ure A.M., Quevauviller Ph. 1999. Improvement of the BCR three step sequential extraction procedure prior to the certification of new sediment and soil reference materials. Journal of Environmental Monitoring, 1, 57-61.

20. Sabienë N., Brazauskienë D.M., Rimmer D. 2004. Determination of heavy metal mobile forms by different extraction methods. Ekologija, 1, 36-41.

21. Seregin I. V., Kozhevnikova A. D. 2006. Physiological role of nickel and its toxic effects on higher plants. Russian Journal of Plant Physiology, 53, 257-277. 